IRA-International Journal of Applied Sciences

ISSN 2455-4499; Vol.03, Issue 03 (2016)

Institute of Research Advances

http://research-advances.org/index.php/IRAJAS

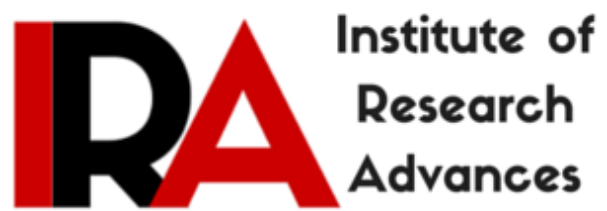

\title{
Studies on the Effects of L-Prolinamide, 5-OXO- L-Prolyl-L-Phenylanyl-4-Hydroxy Compound Produced by Pseudomonas Fluorescence against Cell Wall Protein (3GNU Receptor) of Pythium SPP MTCC 10247
}

\author{
${ }^{1}$ E. Jenisha, ${ }^{2}$ C. Elizabeth Rani Juneius and ${ }^{3}$ Vinoth \\ 1,2,3 Department of Biotechnology, \\ Hindustan College of arts \& science, Tamilnadu, India.
}

DOI: http://dx.doi.org/10.21013/jas.v3.n3.p9

\section{How to cite this paper:}

E. Jenisha, E., Rani Juneius, C., \& Vinoth, V. (2016). Studies on the Effects of LProlinamide, 5-OXO-L-Prolyl-L-Phenylanyl-4-Hydroxy Compound Produced by Pseudomonas Fluorescence against Cell Wall Protein (3GNU Receptor) of Pythium SPP MTCC 10247. IRA-International Journal of Applied Sciences (ISSN 2455-4499), 3(3). doi:http://dx.doi.org/10.21013/jas.v3.n3.p9

(C) Institute of Research Advances

\section{(cc) BY-No}

This works is licensed under a Creative Commons Attribution-Non Commercial 4.0 International License subject to proper citation to the publication source of the work.

Disclaimer: The scholarly papers as reviewed and published by the Institute of Research Advances (IRA) are the views and opinions of their respective authors and are not the views or opinions of the IRA. The IRA disclaims of any harm or loss caused due to the published content to any party. 


\begin{abstract}
The present study was carried out inorder to assess the biocontrol efficiency of Pseudomonas fluorescence against Pythium spp MTCC 10247. The earlier studies have revealed its antifungal properties but the previous reports lack the details about the compounds and the target for the fungi. Hence we have designed our work plan to reveal the compounds present in the secondary metabolites of Pseudomonas fluorescence and the target on the phytopathogens Pythium spp MTCC 10247 which causes plant diseases. Production of secondary metabolites of Pseudomonas fluorescence was carried out and the compounds were characterized by TLC, SDS$P A G E$, and GC-MS. There were 7 peak compounds found out, they are 1,4-diaza2,5-dioxobicyclo[4.3.0] nonane (13,69\%) , 3-isobutylhexahydropyrrolo[1,2a]pyrazine-1,4-dione(10.11\%), Pyrrolo[1,2-a] pyrazine 1,4dione,hexahydro-3-(2methylpropyl(17.79\%) l-Leucine, $N$-cyclopylcarbonyl-pentadecyl ester(7.09\%), 3,6diisobutyl-2,5-piperazinedione (37.62\%), 3-benzylhexahydropyrrolo[1,2A]pyrazine-1,4-dione (8.52\%), L-prolinamide, 5-oxo-l-prolyl-l-phenylanyl-4hydroxy(5.19\%). Antifungal activity of the ethyl acetate extract of the secondary metabolites were examined against Pythium spp MTCC 10247 and result revealed that the lag period of the fungi was double fold higher than the control and the compounds were fungi static because there was a 57\% of growth reduction after $7^{\text {th }}$ day of incubation period. All the seven compounds were used for molecular docking study and result showed higher score value with L-prolinamide, 5-oxo-l-prolyl-lphenylanyl-4-hydroxy against cell wall protein (3GNU receptor) Pythium spp MTCC 10247.
\end{abstract}

Key Words: Pseudomonas fluorescence, Pythium spp MTCC No 10247, GC-MS, Anti-fungal activity, molecular docking, L-prolinamide, 5-oxo-l-prolyl-l-phenylanyl4-hydroxy, 3GNU.

\title{
Introduction:
}

Paddy soil Bacteria which are have potential to control destructive diseases are distributed in many genera. Among them Pseudomonas fluorescence are most effective bacteria for bio control of soil and foliar disease. Pseudomonas fluorescence which have various modes of action especially antibiotic production, rhizosphere colonization etc., would certainly be potential bio control agents for the management of pest and crop plant diseases [1,2].

More than 10,000 species of fungi which can cause disease in paddy plants. most commonly cause diseases in agricultural crops are Plasmodiophoromycetes (cause club root of crucifers, root disease of cereals and powdery scab of potato), Oomycetes (cause seedling damping-off, late blight, downy mildews, and white rust disease), Zygomycetes (cause soft rot of fruit), Ascomycetes and Deuteromycetes (cause leaf spots, blights, cankers, fruit spots, fruit rots, anthracnoses, stem rots, root rots, vascular wilts, soft rot), and Basidomycetes (cause rust and smut diseases [3,4].

Technological improvement, which have more effective use of natural resources, is required in agriculture. Many microbial antagonists have antagonistic activities against plant fungal pathogens, such as Pseudomonas fluorescens, Agrobacterium radiobacter, Bacillus subtilis, B. cereus, B. amyloliquefaciens, Trichoderma viride, Trichoderma harzianum, Burkholderia cepacia, Saccharomyces spp and Gliocadium virens [5, 6, 7].

Some of bacteria, fungal pathogens causes serious damage in agriculture, finally losses of yield, quality and profit. Chemical insecticides are normally used against 
phytopathogens. Due to serious demerits of using chemical insecticides, bio insecticides or bio pesticides are used as Alternatives, enhance crop yield by growth promoting attributes of environment friendly microbes, this method has been developed successfully during the last few years. Many organism which are shown to have pathogenic activity naturally .secondary metabolites produced by Pseudomonas fluorescence showed bio control activity against the soil borne Phytopathogenic fungi and has the potential to produce known secondary metabolites such as siderophore, antibiotic, voltaic compound ,HCN ,Protease and phytohormones that showed the antagonistic activity against Macrophomina phaseolina, Rhizoctonia solani, Phytophthora nicotianae var. parasitica, Pythium sp. and Fusarium spp [8,9].

\section{Materials \& Methods:}

\section{Collection of Sample:}

The commercially available bio pesticide Pseudomonas fluorescence was collected from the farmers of Wayanadu, Kerala and which was used for the further study to find out the similar biocontrol efficiency of the bacteria against the predominat pests infesting the crops of Tiruporur agriculture area of Tamil Nadu

\section{Isolation of Pseudomonas fluorescence:}

Pseudomonas fluorescence biopesticide powder was collected from Wayanadu, kerala was further reviwed using nutrient agar and King's B medium[10].

\section{Production of Biomass \& Secondary Metabolites}

Pseudomonas fluorescence isolated using the solid media was inoculated in two conical flasks containing $100 \mathrm{ml}$ of sterile Nutrient broth and two conical flasks containing $100 \mathrm{ml}$ of sterile King's B broth. The media were incubated at $37^{\circ} \mathrm{C}$ and Biomass was collected after 48 hours by centrifugation at 10,000rpm for 30 minutes. Secondary metabolite extraction was done after 72 hours of incubation period [11].

\section{Extraction of Secondary Metabolites}

The 72 hours old culture was used for this extraction. Culture was centrifuged at $10,000 \mathrm{rpm}$ for 30 minutes and the supernatant was collected. Solvent extraction procedure was carried out using ethyl acetate (1:1). Middle layer was collected and samples were air dried and used for further characterization [12].

\section{Extraction of Secondary Metabolites by Ethyl Acetate Solvent Extraction Method}

The K'B broth was centrifuged and the $40 \mathrm{ml}$ of supernatant was separated.50 $\mathrm{ml}$ of ethyl acetate and $50 \mathrm{ml}$ of supernatant are transfer in separating funnel and is mixed for 30mins. Then the funnel was kept in stand at room temperature for three hours. After 3 hours 3 layers were separated out. The three layers were carefully collected out. The middle layer was used for further analysis [13].

\section{Thin Layer Chromatography}

The ethyl acetate extract samples were applied on the bottom of the activated TLC plate using capillary tubes. It was then kept in TLC tank containing the mixture of chloroform: ethyl acetate: acetic acid in the ratio of 100:80:20 ml .The top of the TLC tank was closed with a thick glass plate to avoid the evaporation of solvents. The mobile phase moved up by capillary action and thus the active constituents were separated based on their solubility. The TLC plate was take out when the solvent front reaches the top of the plate. Then the $2 \%$ ferric chloride solution was sprayed on plate and dried in 10 minutes in hot air oven. Then the TLC plate viewed under UV 
light. All the sample have fluorescent nature, thus fluoresced under UV light. The TLC plates showed fluorescent bands/compounds.

\section{Thin Layer Chromatography: Amino Acid}

Thin layer chromatography was used to check the active constituents present in Pseudomonas fluorescence (ethyl acetate)

\section{SDS PAGE [Sodium Dodicylsulphate Polyacrylamide Gel Electrophoresis]:}

10\%Stock acrylamide-13.3ml, Tris HCL- $8 \mathrm{ml}$ [ph-8.8], Water-18.1ml, APS-200 $\mu$,

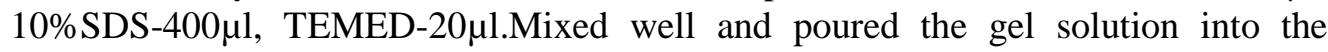
chamber and distilled water was added to top of the gel and left for 30 minutes.

$4 \%$ Stock acrylamide-1.35ml,Tris HCL-1ml [ph-6.8], Water-7.5ml,APS$50 \mu 1,10 \%$ SDS-100 $\mu 1$, TEMED-10 $\mu 1$.the stacking gel mixture was poured into top of the chamber and comb was placed and allowed the gel to set 30mins.After stacking polymerized, the comb was removed carefully without damaging the wells. Clip was removed and bottom site of the spacers was removed. Electrode buffer was filled with electrophoresis apparatus. The gel plate inserted in to the electrophoresis apparatus.

A $200 \mu \mathrm{l}$ of sample buffer and sample was mixed well and heated it for 2 minutes, cool it, $50 \mu \mathrm{l}$ of sample was loaded in to the each well and run the sample.

After electrophoresis the chamber was removed from the electrophoresis apparatus. The side spaces were removed and gel was removed carefully from the chamber. The gel was transferred in to clean plastic container. Then the gel was kept inside the staining solution comassive blue solution overnight. Stain was discarded and detainer was done.

\section{GC-MS (Gas Chromatography and Mass Spectrometry):}

A $200 \mu 1$ sample was taken in beaker and ethyl acetate was added to it and is mixed by pipetting. Sample mixer was taken in syringe, 0.2 PTFF FILTER was inserted in syringe and test samples were filtered in $1.5 \mathrm{ml}$ of vial tube. $\mathrm{In} 4 \mathrm{ml}$ vial tube ethyl acetate was added. This 2 vial tubes were kept in injector, in injector the samples was washed and $1 \mu \mathrm{l}$ sample was injected in to inlet. After 43minutes the result peaks was observed in monitor.

\section{Antifungal Activity:}

PDA was prepared and sterilized at $121^{\circ} \mathrm{c}$ for 15 minutes. After sterilization the media was poured in Petriplates plate marked as positive control and control. In other plate $10 \mathrm{ml}$ media and $200 \mu \mathrm{l}$ compounds are mixed well and poured it in the plates it was marked as test, allowed to solidify. Then the loop of Pythium spp MTCC 10247 culture was inoculated in test plate and positive control plate in the centre of plate. The plate was sealed and kept it in room temperature $[14,15]$.

\section{Molecular Docking:}

Molegro Virtual Docker is an integrated platform for predicting protein - ligand interactions (GC-MS 7 Major compounds and 3GNU Pythium spp MTCC 10247). Molegro Virtual Docker handles all aspects of the docking process from preparation of the molecules to determination of the potential binding sites of the target protein, and prediction of the binding modes of the ligands. The Molegro Virtual Docker (MVD) has been shown to yield higher docking accuracy than other state-of-the-art docking product [16]. 


\section{Results and Discussion:}

Pseudomonas fluorescence isolated by streak plate (King's B Media) method was found to be yellowish pigment on King's B revealed by UV Tran illuminator (fig 1). The fluorescing colonies were identified by phenotypic methods of The Bergy's Manual of systemic bacteriology (table 1). The results were shown in the table 1. Secondary metabolites of Pseudomonas fluorescence produced by 48 hours King's B broth, metabolic compounds were characterized from solvent extraction ( ethyl acetate) method, Phenolic compounds were identified by Thin Layer Chromotography. The Gas chromatography and Mass Spectometry of P.fluorescence ethyl acetate crude extract shows the appearance of the seven major compounds at different retention times. The results were shown in (table 2).

Isolated crude extracted Pseudomonas fluorescence were evaluated for antifungal activity against Pythium spp MTCC 10247.Mycelium growth of the Pythium spp MTCC 10247 were reduced after the treatment with Pseudomonas fluorescence crude extracted in comparison with the control. The results were shown in the (table 3 ). The growth behaviour of the test fungi Pythium spp MTCC 10247 with crude extract of antagonistic bacteria Pseudomonas fluorescence in $2^{\text {nd }}$ day incubation period no growth in test plate and positive control plate (100\% incubation of mycelium growth of Pythium spp MTCC 10247 ) ， $3^{\text {rd }}$ day incubation period no growth in test plate, $0.3 \mathrm{~cm}$ mycelium growth in positive control plate( $100 \%$ incubation of mycelium growth of Pythium spp MTCC 10247), $4^{\text {th }}$ day incubation period no growth in test plate , $3 \mathrm{~cm}$ mycelium growth in positive control plate( $100 \%$ incubation of mycelium growth of Pythium spp MTCC 10247), $5^{\text {th }}$ day incubation period no growth in test plate, $5 \mathrm{~cm}$ mycelium growth in positive control plate( $100 \%$ incubation of mycelium growth of Pythium spp MTCC 10247), $6^{\text {th }}$ day incubation period $1 \mathrm{~cm}$ mycelium growth in test plate, $7 \mathrm{~cm}$ mycelium growth in positive control plate( $86 \%$ incubation of mycelium growth of Pythium spp MTCC 10247), $7^{\text {th }}$ day incubation period $3 \mathrm{~cm}$ mycelium growth in test plate, $7 \mathrm{~cm}$ mycelium growth in positive control plate $57 \%$ incubation of mycelium growth of Pythium spp MTCC 10247) (fig 2) .

In molecular docking the antibiotics of 7 ligands of Pseudomonas fluorescence obtained from GC-MS result is dock on 3GNU receptor of Pythium spp (Table 4). Docking results revelled the docking score of L-Prolinamide,5-Oxo-L-Prolyl-LPhenylalanyhydroxy(C19H24N4O5) on -147.511 and they had formed -13.795 hydrogen bond with the receptor(table 5) .based on the docking score results among the 7 compound this compound have higher binding affinity with the cell wall of Pythium spp (3GNU receptor) therefore the fungi shows sensitivity to Pseudomonas fluorescence of this compound L-Prolinamide,5-Oxo-L-Prolyl-L-Phenylalanyl-4Hydroxy(fig 3,4,5,6,7).

The antifungal activity of P.fluorescence had reported against the P.oryzae and R.solani (17) Pseudomonas fluorescence was shown to effectively inhibit P.oryzae and R.solani by agar plating method reported that P.fluorescence inhibit a maximum of (50-85\%) growth of 2 pathogens when compare to the control. The antifungal activity of P.fluorescence R21, F113 had reported against the Pythium spp (18) P. fluorescence metabolites 2, 4-diacetylphloroglucinol (DAPG). was shown to effectively inhibit Pythium spp By agar plating method reported that P.fluorescence R21 effectively inhibit a maximum of (58.3\%) growth of Pythium spp and P.fluorescence F113 effectively inhibit a maximum of $(66.7 \%)$ growth of Pythium spp when compare to control. In ours Pseudomonas fluorescence was effectively inhibit $(5 \mathrm{~cm})$ the mycelial growth Pythium spp. 
The antifungal activity of Pseudomonas fluorescence EBC5, EBC6, EBC7 had reported that P.fluorescence against the Pythium aphanidermatum(19) P.fluorescence EBC 5, EBC 7 and EBC 6 recorded that inhibit a minimum mycelial growth (28.00, 30.66 and $33.33 \mathrm{~mm}$, respectively) with maximum inhibition zone of $(12.33,11.66$ and $11.08 \mathrm{~mm}$, respectively) of Pythium aphanidermatum over control. In ours studies Pseudomonas fluorescence was effectively inhibit $(5 \mathrm{~cm})$ the mycelial growth Pythium spp. The in vitro action of $P$. fluorescens against $P$. aphanidermatum obvious by the inhibition zones shows fungal activity of the bacterium. (20) Most authors showed antimicrobial activity of bacteria, particularly Pseudomonas species on fungal pathogens. Antifungal metabolite of Pseudomonas antimicrobial inhibited efficiently showed the establishment of inhibition zone due to in vitro antifungal activity of. Microscopic observations of mycelium tissue inside inhibition zone showed the absence of spore and the denaturation of the mycelium. The culture of a portion of this zone on the new PDA could not allow the mycelium development. This result could be suggested that compounds released by the bacterium are fungicides.

This result was also suggested hypothesis depending that $P$. fluorescence produced antibiotics responsible of the bio protection. Indeed, it was isolated more secondary substances produce by $P$. fluorescence which were fungicides antioomycete properties. In ours studies Pseudomonas fluorescence was effectively inhibit $(5 \mathrm{~cm})$ the mycelial growth Pythium spp. Pseudomonas fluorescence was effectively inhibit (57\%) the mycelial growth of Pythium spp(Table 3).

Investigation on microbial metabolites is gaining greater momentum in the agrochemical industry as a source for the development of new pesticide products. Several such products have been developed and used as insecticide, bactericide, fungicide, acaricide, insecticide or acaricide in agriculture. However, research on new metabolites and its development, as agrochemical by fermentation technology has not been addressed adequately in India. Therefore, it is considered worthwhile to generate reliable data on the isolation, production, productivity and bio efficacy of antifungal metabolites from some native $P$. fluorescence. The metabolite(L-prolinamide,5-oxo-1prolyl-1-phenylanyl-4-hydroxy) was isolated the metabolite were extracted from $P$.fluorescence using ethyl acetate and studied bio control efficiency of solvent against the Pythium spp MTCC 10247, the metabolite extracted with ethyl acetate was effectively inhibited(60\%).and ours docking studies Pseudomonas fluorescence metabolite(L-prolinamide,5-oxo-l-prolyl-l-phenylanyl-4-hydroxy) which dock the 3GNU Pythium cell wall protein which confirm the presence antifungal compound in P.fluorescence it inhibiting the Pythium spp MTCC10247 growth and is all so kill the paddy rice leaf folder pest (Cnaphalocrocis medinalis) comparing to others this investigation shows better control when compare to the control.

\section{Conclusions:}

Beneficial paddy soil bacteria Pseudomonas fluorescence was able to produce maximum concentration L-prolinamide, 5-oxo-l-prolyl-1-phenylanyl-4-hydroxy which possess antifungal activity against Pythium spp MTCC 10247, which can be extended with various phytopathogens for further application. . The presented data exhibit the antifungal activity of Pseudomonas fluorescence and indicate the possibility of using Pseudomonas fluorescence as a biological control agent of some plant pathogenic fungi. However, this requires further screening of a large number of Pseudomonas fluorescence from different regions of India. The antimicrobial activity of Pseudomonas fluorescence may be attributed to the various phytochemical constituents have even more potency with respect to the inhibition of microbes. 


\section{Acknowledgement}

The authors grateful to the Hindustan College of Arts \& Science, Chennai, Tamil nadu, India for providing the necessary facilities as and when needed.

\section{References:}

1. B. Meena and T. Marimuthu, Effect of application methods of Pseudomonas fluorescence for the late leaf spot of groundnut management, JBiopest 5(1): 1-6.

2. Roy Manidipa1 et.al. Research Pseudomonads: Potential Bio control agents of Rice Diseases 2007, Journal of Agriculture and Forestry Sciences ISSN 2320-6063 Vol. 1(9).

3. Shankar Kumar Pandey and Shyam Chandra Roy Chandel Efficacy of Pseudomonas as bio control agent against plant pathogen. International journal of current microbiology and applied science2014, volume 3. Pp. 493-500.

4. Weller D. M. Pseudomonas bio control agents of soil borne pathogens, 2007. Phytopathology 97:250-256.

5. R.P.Dhanya and S.Cynthia Adeline A study on the Bio control of phytopathogens of Vigna radiata using Pseudomonas fluorescence in Sustainable Agriculture. International journals of current microbiology 2004. ISSN: 2319-7706 Volume 3 Number 10 (2014) pp. 114-120nd applied sciences.

6. Duraisamy Saravanakumar et.al, Fluorescent Pseudomonad mixtures mediate disease resistance in rice plants against sheath rot (Sarocladium oryzae) disease 2008 International Organization for Biological Control (IOBC).

7. Aiyer, A.K. Field crops of India1958. The Bangalore Printing and Publishing Co., Ltd., Pp. 129133.

8. Shalini and R Srivastava. Screening for Antifungal Activity of Pseudomonas Fluorescence against Phytopathogenic fungi. The Internet Journal of Microbiology. 2007 Volume 5 Number 2.

9. Reddy KRN, Choudary KA and Reddy MS. Antifungal metabolites of Pseudomonas fluorescence isolated from rhizosphere of rice crop 2007. J Mycol Pl Pathol 37(2).

10. Wafaa M. Haggag and Mostafa EI Sound Production and optimization of Pseudomonas fluorescence biomass and metabolites for bio control of Strawberry Grey Mould 2012, American journal of plant science, 3, 836-845.

11. K.E. Poorni*, A. Manikandan, S. Geethanjali and Petcy. K. Percy Production of Pseudomonas fluorescence from agricultural wastes and its application in the preservation of selected vegetables 2010, Advances in Applied Science Research, 2011, 2 (2): 156-160

12. Prasanna Reddy Battu and MS Reddy, isolation of secondary metabolites from Pseudomonas fluorescence and its characterization (2009). Asian Research chem2 (1).

13. Vanitha and R Ramjegathesh, Bio Control Potential of Pseudomonas fluorescens against Coleus Root Rot Disease (2014), Plant pathology and microbiology 5:1.

14. Vishal Kumar Deshwal, Pseudomonas aeruginosa As Biological Control Agent against Plant Pathogenic Fungus Sclerotina sclerotiorum (2012), International journal of plant, animal and environmental science volume 2, issue 1.

15. Anitha, K. and Tripathi, N. N. Laboratory screening of fungal and bacterial antagonists against Rhizoctonia solani and Pythium aphanidermatum 
(Edson) Fitz. Inciting seedling diseases of okra 2001. Indian Journal of Plant Protection, 29: 46-148.

16. G. N. Gupta, V. K. Singh and V. Prakash1 molecular modelling and docking studies of cold active lipase from Pseudomonas fluorescence 2015, international journal of applied biology and pharmaceutical technology Volume-6, Issue-1.

17. Prasanna Reddy Battu and MS Reddy and K. Vijay Krishna Kumar Characterization of antifungal metabolites of Pseudomonas fluorescence and their effect on mycelial growth of Magnaporthe grisea and Rhizoctonia solani(2009), international journal of pharm Tech Research CODEN(USA) :IJPRIF Vol.1,No.4,pp 1490-1493.

18. Phrueksa lawongsa Bio control of Phytopathogens by Pseudomonas fluorescence R21, Isolated from Rice Rhizosphere in Thailand (2012). IJERD - International Journal of Environmental and Rural Development 3-1.

19. Muthukumar. A, Bhaskaran.R and K. Sanjeevkumar. Efficacy of endophytic Pseudomonas fluorescence (Trevisan) migula against chilli damping-off. Journal of Bio pesticides 3(1 Special Issue) 105 - 109 (2010).

20. Dodo boni and Clovis koffi et al., Biological control of Pythium aphanidermatum causalagent of root and/or collar rots of papaya (Caricapapaya) by Pseudomonas fluorescens 2014; European Journal of $\begin{array}{lllll}\text { Biotechnology and } & \text { (6): }\end{array}$ 
(Tables \& Figures)

Table 1: Showing Biochemical characterization of Pseudomonas fluorescence.

\begin{tabular}{|c|l|l|}
\hline S.NO & NAME OF TEST & RESULT \\
\hline 1. & Gram's staining & Gram negative \\
\hline 2. & Motility test & Motile \\
\hline 3. & Flourescence under UV & Positive \\
\hline 4. & Indole test & Negative \\
\hline 5. & Methyl red test & Negative \\
\hline 6. & Vp test & Negative \\
\hline 7. & Gelatin plate test & Positive \\
\hline 8. & Gelatin tube test & Positive \\
\hline 9. & Nitrate test & Positive \\
\hline
\end{tabular}

Table 2: Showing Gas chromatography and Mass Spectometry of P.fluorescence seven major compounds at different retention times.

\begin{tabular}{|l|l|l|l|l|}
\hline $\begin{array}{l}\text { Peak } \\
\#\end{array}$ & R.Time & Area & $\begin{array}{l}\text { Area } \\
\mathbf{\%}\end{array}$ & Compound Names \\
\hline 1 & 21.869 & 1723219 & 13.69 & 1,4-diaza-2,5-dioxobicyclo[4.3.0] nonane \\
\hline 2 & 23.704 & 1272404 & 10.11 & $\begin{array}{l}\text { 3-isobutylhexahydropyrrolo[1,2-a]pyrazine- } \\
\text { 1,4-dione }\end{array}$ \\
\hline 3 & 25.684 & 2239437 & 17.79 & $\begin{array}{l}\text { Pyrrolo[1,2-a]pyrazine-1,4-dione,hexahydro- } \\
\text { 3-(2-methylpropyl) }\end{array}$ \\
\hline 4 & 25.765 & 892870 & 7.09 & $\begin{array}{l}\text { 1-Leucine,N-cyclopylcarbonyl-pentadecyl } \\
\text { ester }\end{array}$ \\
\hline 5 & 29.961 & 4734481 & 37.61 & 3,6-diisobutyl-2,5-piperazinedione \\
\hline 6 & 32.797 & 1072542 & 8.52 & $\begin{array}{l}\text { 3-benzylhexahydropyrrolo[1,2-A]pyrazine- } \\
\text { 1,4-dione }\end{array}$ \\
\hline 7 & 37.452 & 653379 & 5.19 & $\begin{array}{l}\text { L-prolinamide,5-oxo-l-prolyl-1-phenylanyl-4- } \\
\text { hydroxy }\end{array}$ \\
\hline & & 12588332 & 100.00 & \multicolumn{3}{|l}{} \\
\hline
\end{tabular}

Table 3: Showing inhibition of Pseudomonas fluorescence on the mycelium growth of Pythium spp MTCC 10247.

\begin{tabular}{|l|l|l|l|l|l|}
\hline S.NO & $\begin{array}{l}\text { INCUBATION } \\
\text { PERIOD }\end{array}$ & $\begin{array}{l}\text { TEST } \\
\text { PLATE(cm) }\end{array}$ & $\begin{array}{l}\text { POSITVE } \\
\text { CONTROL } \\
\text { PLATE } \\
(\mathbf{c m})\end{array}$ & $\begin{array}{l}\text { \% } \\
\text { inhibition }\end{array}$ & $\begin{array}{l}\text { NEGATIVE } \\
\text { CONTROL } \\
\text { PLATE }\end{array}$ \\
\hline 1. & $2^{\text {nd }}$ day & No growth & No growth & - & No growth \\
\hline 2. & $3^{\text {rd }}$ day & No growth & $0.3 \mathrm{~cm}$ & $100 \%$ & No growth \\
\hline 3. & $4^{\text {th }}$ day & No growth & $3 \mathrm{~cm}$ & $100 \%$ & No growth \\
\hline 4. & $5^{\text {th }}$ day & No growth & $5 \mathrm{~cm}$ & $100 \%$ & No growth \\
\hline 5. & $6^{\text {th }}$ day & $1 \mathrm{~cm}$ & $7 \mathrm{~cm}$ & $86 \%$ & No growth \\
\hline 6. & $7^{\text {th }}$ day & $3 \mathrm{~cm}$ & $7 \mathrm{~cm}$ & $57 \%$ & No growth \\
\hline
\end{tabular}


Table 4: Showing docking score of 7 GC-MS Pseudomonas fluorescence compounds and Pythium spp cell wall $3 \mathrm{GNU}$ receptor.

\begin{tabular}{|l|l|l|l|l|}
\hline Molecular name & Ligand & $\begin{array}{l}\text { Moldock } \\
\text { score }\end{array}$ & $\begin{array}{l}\text { Re rank } \\
\text { score }\end{array}$ & $\begin{array}{l}\text { H } \\
\text { BONDS }\end{array}$ \\
\hline $\begin{array}{l}\text { 1,4-diaza-2,5- } \\
\text { dioxobicyclo[4.3.0] nonane }\end{array}$ & 45588 & -72.007 & -62.7619 & -7.54215 \\
\hline $\begin{array}{l}\text { 3- } \\
\text { isobutylhexahydropyrrolo[1,2- } \\
\text { a]pyrazine-1,4-dione }\end{array}$ & 118054 & -89.4117 & -77.7031 & -2.71803 \\
\hline $\begin{array}{l}\text { Pyrrolo[1,2-a]pyrazine-1,4- } \\
\text { dione,hexahydro-3-(2- } \\
\text { methylpropyl) }\end{array}$ & 50619 & -89.4405 & -75.7725 & -3.54399 \\
\hline $\begin{array}{l}\text { 1-Leucine,N-cyclopylcarbonyl- } \\
\text { pentadecyl ester }\end{array}$ & 185528 & -113.24 & -39.8791 & -3.55647 \\
\hline $\begin{array}{l}\text { 3,6-diisobutyl-2,5- } \\
\text { piperazinedione }\end{array}$ & 141382 & -88.6453 & -69.5163 & -4.68542 \\
\hline $\begin{array}{l}\text { 3- } \\
\text { benzylhexahydropyrrolo[1,2- } \\
\text { A]pyrazine-1,4-dione }\end{array}$ & 166293 & -98.704 & -31.7975 & -9.35383 \\
\hline $\begin{array}{l}\text { L-prolinamide,5-oxo-l-prolyl- } \\
\text { l-phenylanyl-4-hydroxy }\end{array}$ & 326452 & -147.511 & -104.321 & -13.795 \\
\hline
\end{tabular}

Table 5 : Showing the best docking score of L-prolinamide, 5-oxo-1-prolyl-1phenylanyl-4-Hydroxy (326452) and 3GNU receptor.

\begin{tabular}{|l|l|l|l|}
\hline Ligand & MolDockScore & $\begin{array}{l}\text { Rerank } \\
\text { Score }\end{array}$ & H Bond \\
\hline 326452 & -147.511 & -104.231 & -13.795 \\
\hline
\end{tabular}

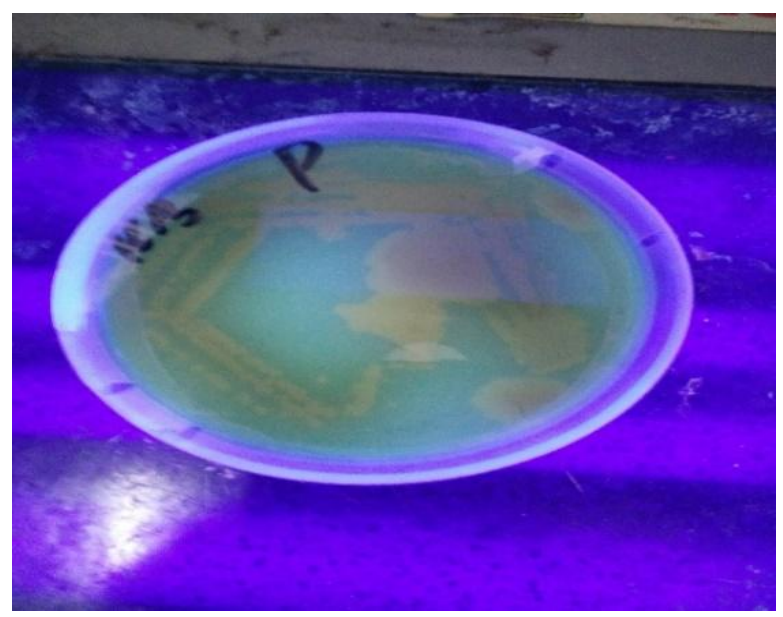

Fig 1: King's B plates shows fluorecence yellow colour colonies and indicates the growth of Pseudomonas fluorescence. 


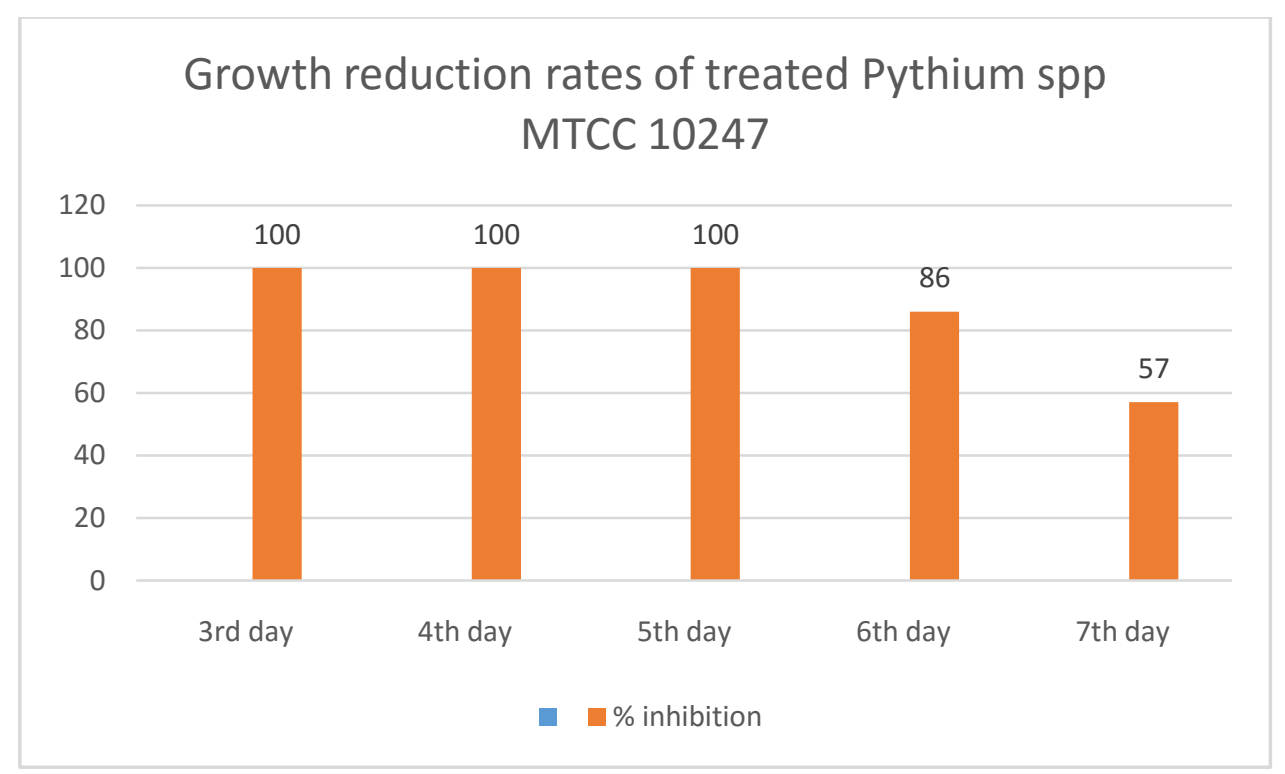

Fig 2: Showing inhibition of Pseudomonas fluorescence on the mycelium growth Of Pythium spp MTCC 10247

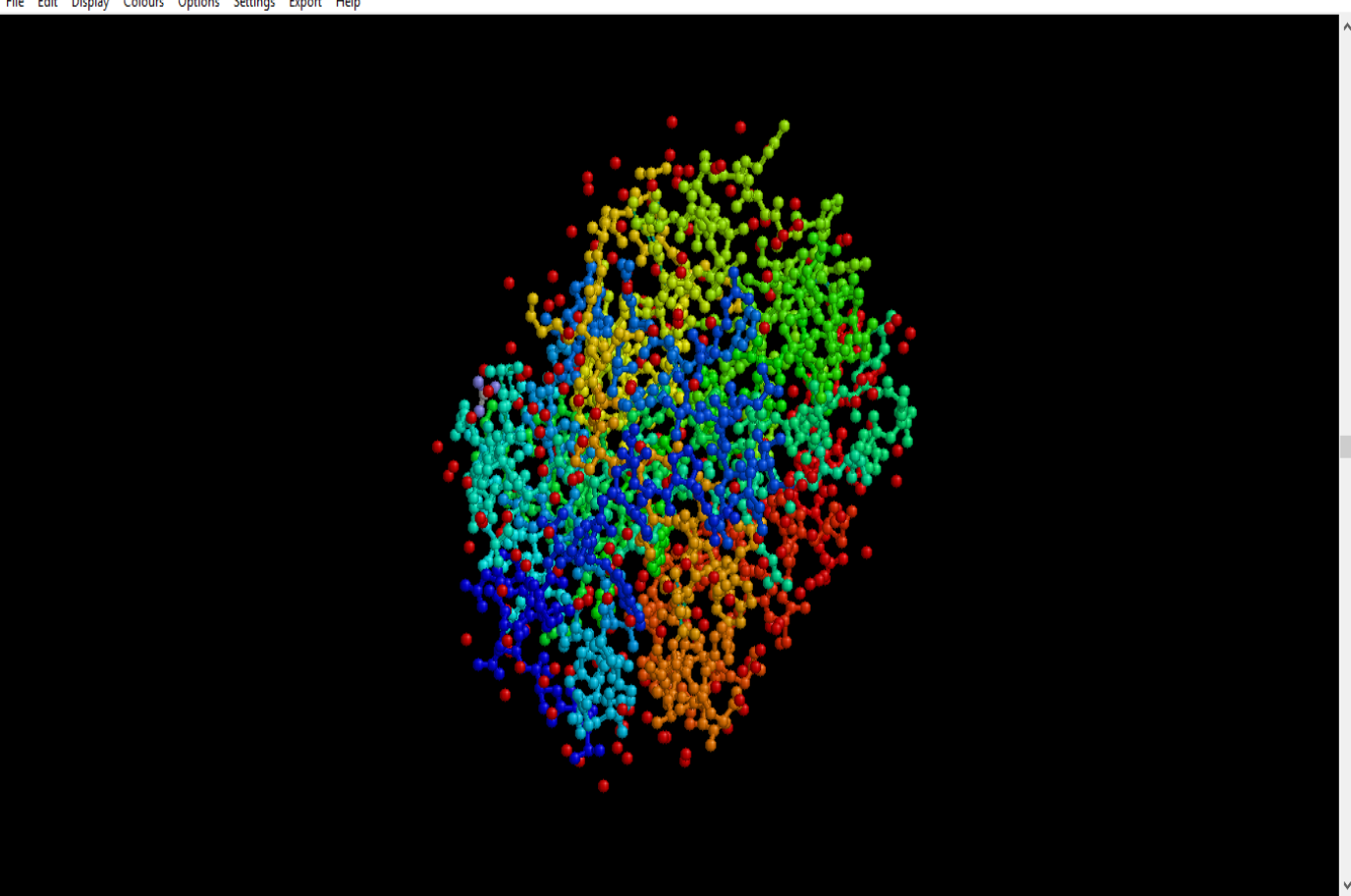

Fig 3: Showing 3D structure of 3GNU receptor 


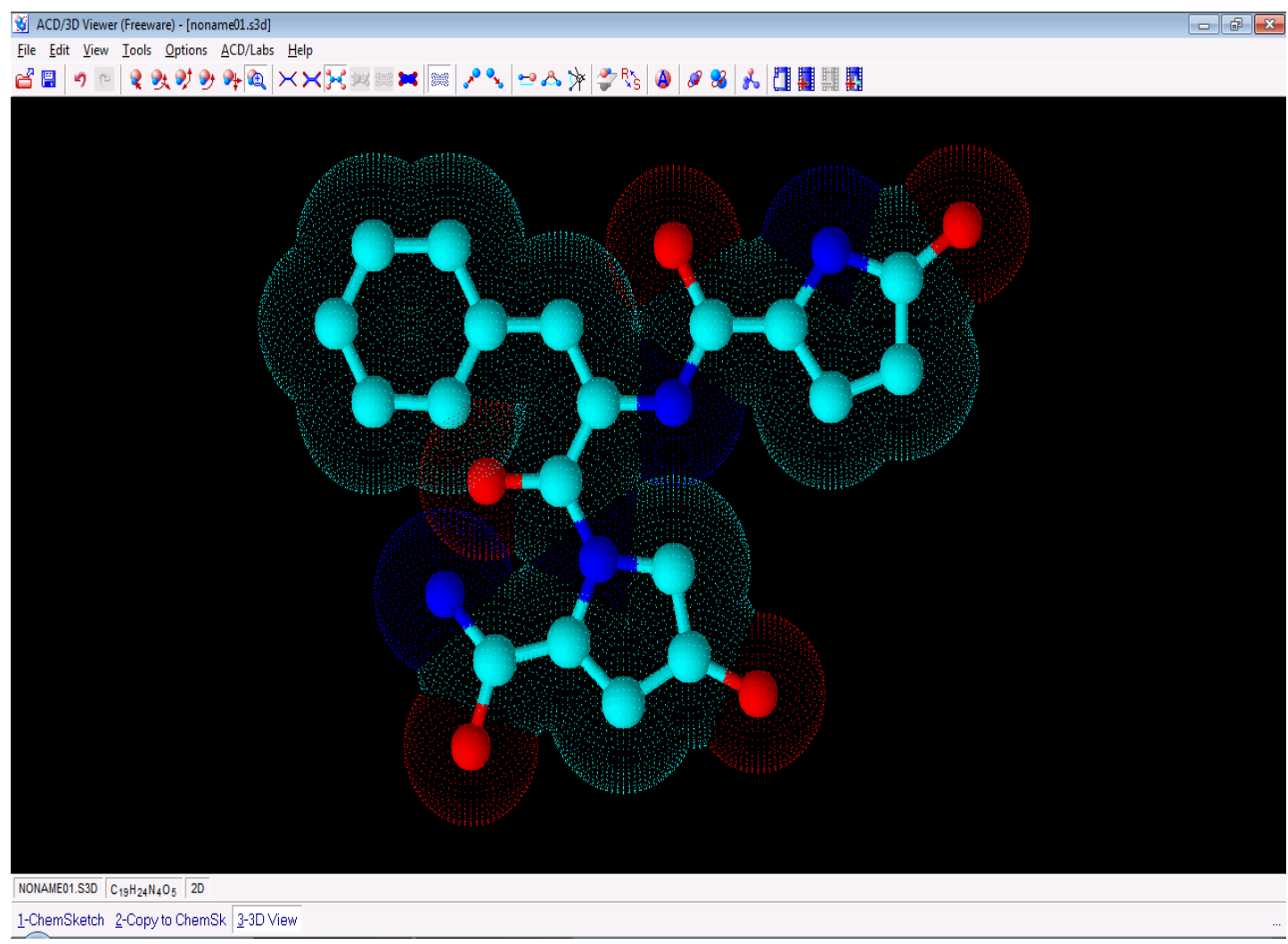

Fig 4: showing 3D Structure of L-prolinamide, 5-oxo-1-prolyl-1-phenylanyl-4hydroxy ligand.

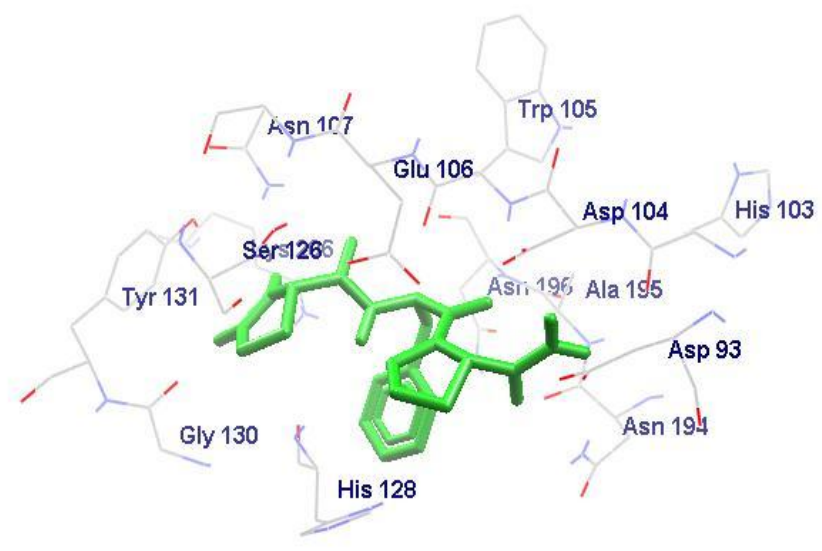

Fig 5: Showing L-Prolinamide, 5-Oxo-L-Prolyl-L-Phenylalanyl-4-Hydroxy (326452) ligand against $3 \mathrm{GNU}$ receptor /ligand pose (C19H24N405). 


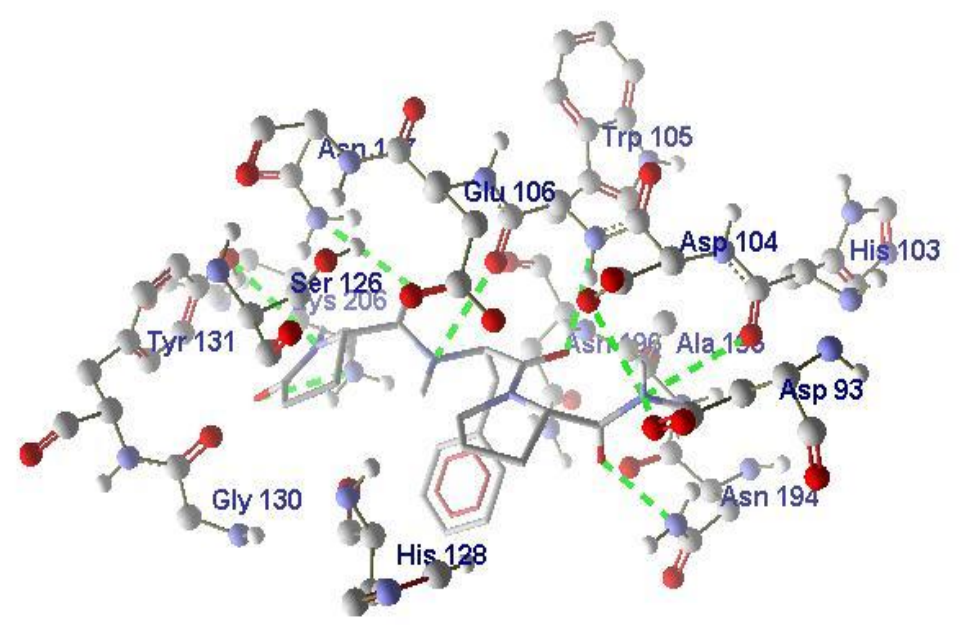

Fig 6: Showing active binding site of L-prolinamide, 5-oxo-1-prolyl-1-phenylanyl-4hydroxy (326452) and 3GNU receptor/ H Bond (Protein present on the surface of Pythium spp MTCC 10247 cell wall has been highlighted in green color).

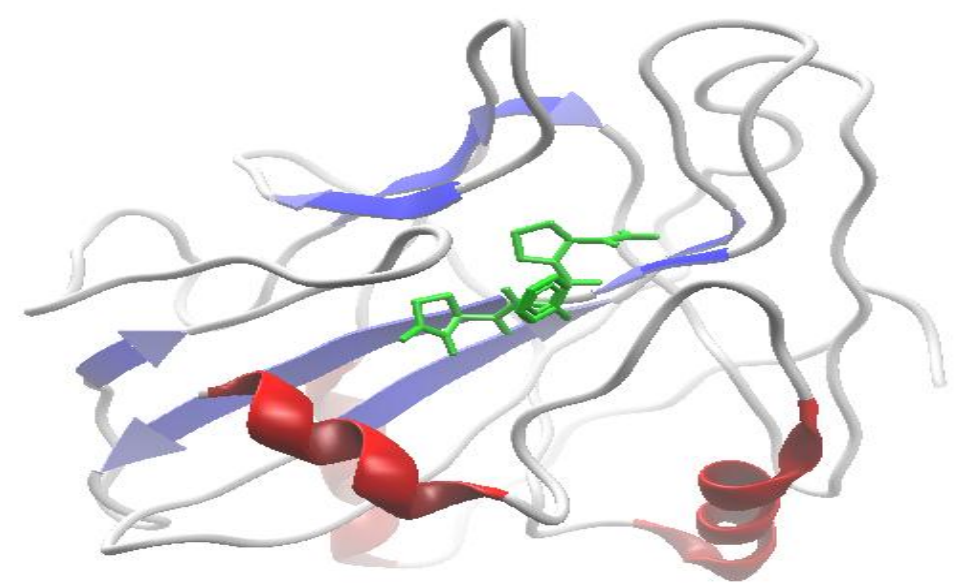

Fig 7: Showing secondary structure L-prolinamide, 5-oxo-1-prolyl-1-phenylanyl-4hydroxy (326452) and 3GNU receptor. 


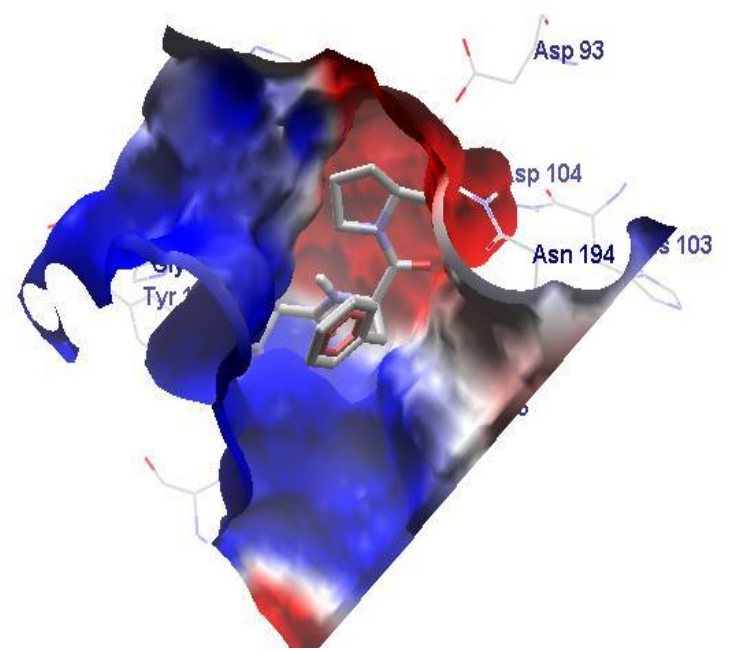

Fig 8: Showing Electrostatic Interaction between L-prolinamide, 5-oxo-1-prolyl-1phenylanyl-4- Hydroxy (326452) and 3GNU receptor. 